\title{
Human Rights Enforcement Through The Implementation of Public Service-Based Criminal Justice
}

\author{
Maroni $^{1}$, Nenny Dwi Ariani ${ }^{2}$ \\ \{maroniunila@gmail.com ${ }^{1}$, nennydwiariani@gmail.com ${ }^{2}$ \} \\ Faculty of Law, University of Lampung, Indonesia ${ }^{1}$, Faculty of Law, University of Lampung, \\ Indonesia $^{2}$
}

\begin{abstract}
The court is one of the administrators of the state's duties in the judiciary, as mandated by the 1945 Constitution. Every state administrator must carry out public services under Law Number 25 of 2009 concerning Public Services. Based on Law Number 8 of 1981 concerning the Criminal Procedure Code, criminal justice in Indonesia demanded transparency, accountability, and equality. Therefore the form of public service of criminal justice in protecting the human rights for justice seekers shall implement the principles of transparency, accountability, participative, and equality before the law in investigating criminal cases in court. Implementing a proper public service-based in criminal justice is expected to improve the performance of criminal investigators in achieving substantial justice and accommodating the legal interests of justice seekers. Moreover, the application of public service in judicial institutions will improve society's prestige to accomplish one the indicator of the state's duties in the judiciary.
\end{abstract}

Keywords: Criminal Justice, Public Service, Human Rights.

\section{Introduction}

A person's status as a suspect or defendant does not necessarily cause the loss of human rights in the criminal justice process. In reality, there are still many violations of justice seekers' human rights in the criminal justice process. The rights of justice seekers tend to be disadvantaged in the criminal justice process due to abuse of power by law enforcers for specific reasons (vertical human rights violations) such as (1) equality of rights; (2) inalienability of rights; and (3) universality of rights.

Abuse of power within the scope of, "The Protection of Human Rights in the Administration of Justice" includes (1) prevention of discrimination; (2) statelessness and refugees; (3) the principle of legality; this includes the principle of non-retroactivity of criminal law; the principle of presumption of innocence and the principle of ne bis in idem; (4) right to life and freedom from inhuman and unusual punishment; (5) right to liberty and prisoners' rights; (6) right to a fair trial; (7) administration of juvenile justice; (8) victims' rights and remedies [1][2]."

In Indonesia, the provisions governing criminal justice procedure is subjected under the Law Number 8 of 1981 concerning the Criminal Procedure Code (KUHAP). However, the Criminal Procedure Code provides inadequate protection for justice seekers' legal interests, 
such as witnesses and victims of criminal acts. The form of protection for witnesses and/or victims solely includes: "(1) compensation due to legal termination of investigation or prosecution (Article 81); (2) merger of claims for compensation in criminal cases (Article 98 paragraph (1)); (3) The witness has the right to receive reimbursement for attending the trial (Article 229 paragraph (1))." Considering the Criminal Procedure Code does not comprehensively regulate the protection of witnesses and victims, various laws and regulations besides the KUHAP have emerged to regulate the protection of witnesses and criminal acts.

For instance, the provisions regarding the protection of witnesses and victims in corruption cases are regulated under Article 15 of Law Number 30 of 2002 concerning the Corruption Eradication Commission. Moreover, provisions related to human rights violations are outlined in Government Regulation Number 2 of 2002 concerning Procedures for Protection of Victims and Witnesses. As for victims of sexual violence cases, it regulated under Law Number 23 of 2004 concerning the Elimination of Domestic Violence. Unfortunately, the aforementioned statutory regulations' existence is still inadequate to protect witnesses and/or victims of criminal acts. One of the concrete examples taken from the case of Endin Wahyudin back in 2001 was when he complained about the Supreme Court Judge's bribery. In this case, he was unfairly accused of defamation and later sentenced to three months imprisonment.

To overcome such conditions, it is necessary to have criminal law enforcement practices that uphold human rights as outlined under the International Bill of Human Rights and related international instruments concerning criminal justice administration. These international bills of human rights include four United Nations (UN) documents, namely:(1) Universal Declaration of Human Rights; (2) International Covenant on Economic, Social and Cultural Rights; (3) International Covenant on Civil and Political Rights; and (4) Optional Protocol to the International Covenant on Civil and Political Rights. Additionally, there are more than 20 international instruments that regulate the protection of human rights in criminal justice administration.

The enforcement of criminal law under the provisions, as mentioned earlier, is a criminal justice process that applies the principles of public service, namely: fast, precise, accurate and have a decent quality. These are in-line with fast, straightforward, accurate, impartial, low cost and free judicial principles as subjected under the Law Number 8 of 1981 concerning Criminal Code Procedures in conjunction with Law Number 48 of 2009 concerning Judicial Power. Also, the principles of public service in the form of transparency, accountability, conditionality, participation, equality before the law, and balance of rights and obligations are in line with the principles of justice based on Almighty God or justice based on God's guidance, namely equality, objectivity, impartiality, and not taking sides, which is the goal of Indonesian justice [3]. Based on that background above, this research will examine problems related to how human rights enforcement through the implementation of public service-based criminal justice?

\section{Literature Review}

\subsection{Protection of Human Rights}

The protection of humans rights explained above is related to the rights of the detained suspect/defendant. Meanwhile, the rights of the defendant related to the administration of the 
bureaucracy of the criminal court include: (1) the defendant has the right to have his case immediately submitted to the trial; (2) notification of the commencement of the trial and the attendance date for the suspect to the court session must be submitted legally; (3) a defendant has the right to obtain a duplication of the inspection report for the sake of his defense, as well as a duplication of the case transfer letter and the indictment letter; (4) The judge is obliged to ask the defendant whether he understands the meaning of the contents of the indictment which has been read out by the public prosecutor; (5) the trial is conducted open to the public; (6) The judge presiding over the session is obliged to guard against being asked questions or an atmosphere that causes the defendant or witness to give answers freely, including questions that are intended to interrupt; (7) The judge shall give sufficient time for the defendant or the legal advisor and the public prosecutor to ask various questions to the witnesses or in the case of filing other evidence; (8) the defendant cannot be afflicted with the burden of proof, namely in the form of various actions that force him to answer or make confessions; (9) the public prosecutor cannot present a witness who is also a defendant in the same case (crown witness), even though the witness has the status of a defendant in the case file which was not tried simultaneously; (10) all evidence submitted must be verified against the testimony of the witnesses presented, and all evidence is shown to the accused; (11) a defendant has the right to be given time to argue against the testimony of a witness after he finished giving his testimony before the trial; (12) a defendant/legal advisor has the right to submit evidence in the form of material or witnesses that mitigate (A de charge), besides being able to present expert witnesses, namely people who have special expertise on a matter related to the case being tried; (13) all forms of objections or important notes submitted by the defendant/legal adviser and public prosecutor which take place in court at their request, the judge orders the clerk to record them; (14) A defendant or his legal adviser has the right to submit a defense which is read openly before the trial [4].

The principles mentioned above align with the least guarantee fair trial set by the A Competent, Independent, and Impartial Tribunal Including: (1) suspects are given information quickly and clearly on the charges against them; (2) sufficient readiness, both time and facilities to defend themselves and communicate with legal advisors; (3) get on the trial as quickly without undue delay; (4) get on trial in his presence; in the 'In Absentia' matter, suspect/defendant must have substantial grounds and conduct based on democratic laws; (5) balanced testimony; (6) the right to appeal; (7) free from "Miss-interpretation of justice"; (8) "Right to Habeas Corpus Mechanism"; (9) Legal Assistance; (10) Equality of Arms Between The Parties; Legality Principle; (11) The Principle of Presumption of Innocence [1].

\subsection{Quality Public Service}

Public service is an activity of providing goods and services to the society by the government, either given directly or through partnerships with the private sector and the community based on the type and intensity of community needs, community capacity, and the market. This concept emphasizes how successful public services are provided through a healthy delivery system. The purpose of public services is to provide the best goods and services for the community. The best goods and services fulfill what is promised or what society needs. Thus, the best public services provide satisfaction to the public, if necessary, to exceed public expectations [5].

People always demand quality public services from public service providers, although these demands are often not in line with expectations because empirically, the public services that have occurred so far are still convoluted, slow, expensive, and displeasing [6]. To overcome this condition, Osborne and Plastic characterize the government (bureaucracy) as 
expected above as 'government-owned by the people', namely the government, which transfers the control authority it has to the people. The community is empowered so that it can control the services provided by bureaucrats. Moreover, people tend to have an exemplary commitment, are more caring and more creative in solving problems, so that society's role in improving public services is needed. Public services will still be borne by the bureaucrats appointed by the state as public servants. Therefore, a strong commitment to serving must be built to be more responsive to community needs and design a more creative and more efficient service model [7].

Moreover, quality public services can also be done with the concept of "wholehearted service," as defined by Patton et al. (2002), which means self-service that reflects emotions, character, beliefs, values, and points of view. In Patricia's concept, the real value in wholehearted service lies in the seriousness of the four "P" attitudes, namely (1) passionate, such as presenting life and vitality at work; (2) progressive, such as being creative and attractive to improve services; (3) proactive, such as the passion for conceiving the right initiatives to achieve service quality; (4) flattering, such as being a personally warm person in welcoming consumers and being more thoughtful in asking any question considered inappropriate [8][6]. Also, quality public services are similar to the meaning of trustworthy governance, namely: democratic, fair, cost-conscious, transparent, accountable [9][10]. These concepts are summarized in the cultural concept of FAST disseminated namely Fathonah, Amanah, Shiddiq, and Tabligh [11].

\section{Methods}

This study uses the normative legal method (library law research) with the type of descriptive analytical research. The data obtained are secondary data from literature sources such as book, journal, articles and internet sites.

\section{Result and Discussion}

The human rights protection for justice seekers in the criminal justice process is conducted in two models, as proposed by Herbert L. Packer, namely the Crime Control Model (CCM) and the Due Process Model (DPM). In CCM, the obligation to work as efficiently as possible is the main requirement so that law enforcement officers' mistakes are tolerated to a certain degree in determining whether someone is guilty. The CCM assumes that everyone involved in the criminal justice process is likely to be guilty. Therefore, the use of power in law enforcement officials' hands must be as maximum as possible. However, there is a concern that officers who are required to work efficiently will neglect human rights in this model.

Whereas in DPM, the criminal justice system is likened to a "conveyor belt" mechanism, and at each particular stage, a "test" is taken whether a process has been carried out properly by officers who operate in their respective authority. The DPM model is made due to the CCM model's concern that only prioritizes the efficiency aspect and caused irregularities in the implementation of the criminal law procedure. Therefore, DPM places more emphasis on implementing the existing legal rules properly and adequately. 
The DPM is based on the "presumption of innocence" principle as the justice system's essential values. The main objective of DPM is to protect those who are genuinely innocent and prosecute those who are truly guilty [12]. If the two models put forward compare to the Criminal Procedure Code (KUHAP) as the law-procedural basis for Indonesia's criminal justice system, it seems that the Criminal Procedure Code adheres to both the CCM and the DPM. It is supported by the fact that several principles regarding both models are contained in the Criminal Procedure Code itself. Those principles illustrate that the Criminal Procedure Code focuses primarily on protecting a suspect or defendant's dignity, as intended by DPM. Meanwhile, the 'constante justitie' principle is in-lined with what is meant by the CCM. In addition, those principles conveyed in its purpose to limit the attitudes and actions of law enforcement officials. These principles should be contained in the Criminal Procedure Code, considering that the criminal procedure law is designed to control law enforcers, not criminals, as stated by Skolnick [13].

The protection of the human rights for suspects or defendant contained in KUHAP is regulated under Article 57 to Article 63, includes: (1) the right to contact a legal advisor; (2) the right to contact and speak with representatives of their countries, for suspects/defendants who are foreign nationals; (3) the right to contact and receive visits from private doctors for the sake of their health; (4) the right to be notified to his family or other people whose assistance is needed regarding his detention; (5) the right to contact and receive visits from parties who have family or other ties; (6) for work or family purposes the right to contact and receive visits from family or other parties, either directly or through a legal advisor; (7) the right to send and receive letters from legal advisors and their families, and writing instruments are provided for this purpose; (8) the right to contact and receive visits of the clergy.

However, the protection for other justice seekers' legal interests, such as witnesses and victims of criminal acts in the Criminal Procedure Code, is still considered inadequate. The form of protection for witnesses and/or victims solely includes: (1) compensation due to legal termination of investigation or prosecution (Article 81); (2) merger of claims for compensation in criminal cases (Article 98 paragraph (1)); (3) The witness has the right to receive reimbursement for attending the trial (Article 229 paragraph (1)). Considering the Criminal Procedure Code does not comprehensively regulate the protection of witnesses and victims, various laws and regulations besides the KUHAP have emerged to regulate the protection of witnesses and criminal acts.

The protection of witnesses and victims in the criminal justice process, outlined in various laws. For instance, the protection for witnesses and victims in corruption cases is regulated under Article 15 of Law Number 30 of 2002 concerning the Corruption Eradication Commission. Moreover, in the scope of human rights, the protection of witnesses and victims is outlined in Government Regulation Number 2 of 2002 concerning Procedures for Protection of Victims and Witnesses and Law Number 23 of 2004 concerning the Elimination of Domestic Violence as for victims of sexual violence cases. However, the legal protection outlined in those mentioned laws and regulations was deemed inadequate. It was needed for the government to enact specific laws regarding the protection of witnesses and victims. This concern then becomes the background of the enactment of Law Number 13 of 2006 concerning Witness and Victim Protection.

The urgency for the protection of witnesses and victims is related to the court's role as a government bureaucratic institution. The court is a government organization expected to become an organ for the community to perceive justice. In optimizing its role as the state's organ in society, the Criminal Procedure Code adopts a service-based model in criminal justice administrations to achieve the highest justice capacity. Judicial institutions, as 
administrators of state duties in the judiciary, possess the same purposes as other state institutions in the executive and legislative sectors in providing service to every citizen and resident of Indonesia. The establishment of the judiciary by the state is one way to fulfill its obligation in providing society to meets their fundamental rights and need as mandated under the 1945 Constitution of the Republic of Indonesia in Law No. 25 of 2009 concerning Public Services. As well as mandated in Law Number 25 of 2009 concerning Public Services.

Based on the explanation of Article 5 paragraph (4) "letter a that public services in this provision are for example, including health services (hospitals and puskesmas), educational services (primary schools, junior high schools, high schools, and colleges), marine navigation (lighthouses and beacons), judicial services, traffic services (traffic lights), security services (police services), and market services."

In this regard, the importance of public services in the administration of criminal justice bureaucracy will determine the government system's effectiveness in fulfilling the administrative service compliance as one of the fundamental needs of every citizen.

Concerning the implementation of the criminal justice bureaucracy, public services, as described above, are essential, considering that the core of public service is excellent service run under four main principles (FPAQ), namely fast, precise, and accurate. These FPAQ principles are in line with the principles of constant just tie, honest and impartial, which underlie the administration of criminal justice in Indonesia under the Law Number 8 of 1981 concerning KUHAP in conjunction with Law Number 48 of 2009 concerning Judicial Power. Besides, the principles of public service in the form of transparency, accountability, conditionality, participation, equality before the law, and balance of rights and obligations are also in line with the principles of justice based on Almighty God or justice based on God's guidance, namely equality, objectivity, impartiality, and not taking sides, which is the goal of Indonesian justice [3].

The implementation of public service principles in the process of implementing criminal justice in the context of protecting the human rights of justice seekers is as follows:

\subsection{Transparency Principle}

The principle of transparency in public services requires services that are open, easy, and accessible adequately to all parties who need them, and easily understood. The principle of transparency is related to human rights to obtain public information as one of the essential features of a democratic country and put forward and upholds the sovereignty of people to accomplish good state administrations. Moreover, public information disclosure is a means of optimizing public supervision of the administration of the state and other Public Organs and any purposes related to the public interest. The right to obtain information is fundamental because the more open the state is to be monitored by the public, the more accountable the state administration is. People's right to obtain information is also relevant for improving the quality of community involvement in the public decision-making process. Public participation or involvement requires a guarantee of the openness of Public Information in Preamble and General Elucidation of Law No. 14 the Year 2008 on Freedom of Information.

The implementation of this principle in the criminal justice process in protecting the human rights of justice seekers, through the provisions of the Supreme Court Circular Letter (SEMA) No. 4 of 2012 concerning the Recording of the Court Process. This provision determines that in order to ensure the implementation of the trial to be more transparent, accountable, and thorough, in future, it is necessary to take an audio-visual recording that directed systematically, regularly, and inseparable from the trial procedure, as an addition for the substitute clerk's records (Article 202 paragraph (1) of Criminal Procedure Code). For 
instance, to accomplish this future purpose, the proceedings at the court shall gradually commence utilizing an audio-visual with the following conditions: (1) The result of the audiovisual recording is a complement to the Trial Minutes; (2) Audio-visual recording is carried out systematically, and its integrity is guaranteed; (3) Audio-visual recordings of the trial shall be managed by the Registrar and (4) Audio-visual recordings as part of bundle A.

\subsection{Accountability Principle}

Based on the principle of accountability, public service providers' services must be accountable following the provisions of laws and regulations. This principle requires that all public service providers' activities, both at the process and outcome level, must be accounted for following the provisions of laws and regulations. Concerning the criminal justice bureaucracy, this means that examining criminal cases by judicial officials, in this case, judges and clerks, must comply with the provisions of laws and regulations. Compliance is demanded since there is no absolute freedom without responsibility. Judicial independence must be balanced with Judicial Accountability. Impartiality, honesty, fairness, transparency, and professionalism are attitudes that must be upheld by each Judge as a form of accountability for the judicial power they possessed [14].

The implementation of this principle in the criminal justice bureaucracy in the framework of Human rights protections of justice seekers conducted by condition as follows: (1) the public can directly access a judge's decision after it is read out; (2) function of a legal institution with a dissenting opinion by requiring every Judge to draft a decision, especially legal considerations that will be used as a reference for the final decision by the panel of judges. The concept of each Judge's decision is an integral part of the final decision of panel judges, meaning that the concept of the decision made by each Judge must be attached to the panel's final decision. Since principally the Judge's responsibility to conceive his decision is utterly individual, the Judge is independent and solely responsible to God Almighty. More than that, as a law enforcer, the Judge has an ideology and dissenting opinions that explicate the transparency and clarity of the judges' accountability for their professional duties. According to Article 14 paragraph (2), "the court's decision and (3) Law Number 48 of 2009 is required. In a deliberation session, each Judge must convey a written consideration or opinion regarding the case being examined and become an integral part of the decision. If a unanimous consensus cannot reach a deliberative session, the Judge's different opinions must be included in the decision." (3) opportunities are opened to ensure court decisions are guaranteed by independent institutions such as the Judicial Commission, academics, and Community Social Institutions (NGOs) that focus on justice.

\subsection{Participatory Principles}

The definition of participatory principle is a service that encourages society's participation in providing public services by taking into accounts the aspirations, needs, and expectations of the society. The embodiment of this principle in the criminal justice process in the framework of protecting the rights of justice seekers, namely: (1) by carrying out the functionalization of legal institutions for Case Settlement outside the court (adorning bitten process). This legal institution already exists based on the provisions of Article 82 of the Criminal Code called afoot (Article 82 of the Criminal Code), which regulates that if an offense is punishable only with a fine, then the prosecution can be avoided by paying the maximum fine directly [15]. In this case, a diversion mechanism is used, namely for minor cases resolved outside the court (non-litigation process) with the victim; (2) using the Plea Bargain mechanism or negotiating demands. Plea Bargain is an agreement mechanism in 
criminal cases between the public prosecutor and the defendant, where the defendant must admit guilt in exchange for the prosecutor's offer or when the Judge has mentioned informally that the Judge will reduce the sentence if the defendant admits guilt. Plea Bargain's natural principle is "based on the idea that to prevent the inability of the court institution to handle cases that are getting more and more massive overtime. This mechanism is then believed not to violate legal principles and is morally acceptable because both parties agree voluntarily to receive benefits from this mechanism."

In Indonesia, a smuggling case is frequently settled out of court by paying a "conciliation fine" agreed between the suspect and the prosecutor that the Attorney General agrees [15]. The Attorney General's determination is called shacking based on the legal basis of opportunity. The policy was imitated by the Wet op de economics delicate Nederland in 1950.

\subsection{Equality before the Law Principle}

The principle of equality before the law in public services means services that do not discriminate against justice seekers from any aspect, especially ethnicity, race, religion, class, social status, etc. The implementation of this principle in the criminal justice process, namely: (1) there is an obligation that every defendant who is incapable of all criminal cases receives free legal assistance; (2) recognition of the existence of witnesses in the criminal justice process. The witness's position in the Criminal Procedure Code is unfortunately inadequate, and it is proven that there are very few provisions of the Criminal Procedure Code regulating the rights of witnesses compared to their obligations. The Criminal Procedure Code views witnesses about their obligations. Even if a witness refuses his obligation, he can be held hostage in a state detention center for fourteen days based on the provisions of Article 161 paragraph (1) of the Criminal Procedure Code.

\section{Conclusion}

Based on the study explained above, the implementation of public service in criminal justice bureaucracy in the context of human rights protection on justice seekers is a bureaucratic model that accommodates the parties involved in the criminal justice process. Moreover, the recommendation to accommodate the interests of these parties is to implement values of justice outlined in Pancasila as the philosophy or way of life of the Indonesian people related to the purpose of public service to provide the best goods and services for the society in the sense that the best goods and services fulfill what is promised or what society needs. However, the best public services provide satisfaction to the public, if necessary, exceeding public expectations.

The embodiment of public service principles in the criminal justice bureaucracy, namely the improvement of the provisions of the trial procedure law, including making public service the principle of the trial. These improvements include: (1) the existence of provisions on the obligation to carry out transparency in the process of examining criminal cases by means of, among other things, the use of information technology facilities; (2) there is a provision that every decision read out by the panel of judges can be directly accessed by the public; (3) there is a provision on the functionalization of a dissenting opinion legal institution in which each Judge is obliged to draft a decision as material for deliberation by the panel of judges and as an attachment to the final decision; (4) there is an obligation to conduct examination of some instances by independent institutions; (5) there is a provision on the authority of the KPN to 
combine cases against the same defendant; (6) there is a provision on the authority of the KPN to appoint a single judge in cases deemed easy to prove; (7) there are provisions regarding the functionalization of legal institutions for Out-of-Court Case Settlements (adorning bitten process); (8) there are provisions on the mechanism for Negotiation on Claims (plea bargain) that apply as in the standard law system; (9) there is a provision on the obligation of free legal aid to all criminal cases for an incapacitated defendant, (10) there is a provision on witness protection in criminal proceedings.

\section{References}

[1] Muladi, “Membangun 'Grand Design' Kebijakan Penegakan Hukum Pidana Yang Mengakomodasi Keadilan di Era Demokrasi," Bandar Lampung, 2011.

[2] R. Marbun, "Grand Design Politik Hukum Pidana dan Sistem Hukum Pidana Indonesia Berdasarkan Pancasila dan Undang-Undang Dasar Negara Republik Indonesia 1945," PADJADJARAN J. Ilmu Huk. (Journal Law), vol. 1, no. 3, pp. 558-577, 2014.

[3] B. N. Arief, Pendekatan Keilmuan dan Pendekatan Religius dalam Rangka Optimalisasi Penegakan Hukum (Pidana) di Indonesia. Semarang: Badan Penerbit Universitas Diponegoro, 2010.

[4] B. Widjojanto, Fair Trial: Prinsip-Prinsip Peradilan yang Adil dan Tidak Memihak. Jakarta: YLBHI, 1997.

[5] Y. T. Keban, "Etika Pelayanan Publik: Pergeseran Paradigma, Dilema dan Implikasinya bagi Pelayanan Publik di Indonesia," bappenas.go.id, no. March, p. 2011, 2011.

[6] L. P. Sinambela, Reformasi Pelayanan Publik: Teori, Kebijakan, dan Implementasi. Jakarta: Bumi Aksara, 2007.

[7] D. Osborne and P. Plastrik, Memangkas Birokrasi: Lima Strategi Menuju PemerintahanWirausaha. Jakarta: Pustaka Publik, 1999.

[8] W. D. Patton, S. Witt, N. Lovrich, and P. J. Fredericsen, Human Resource Management: The Public Service Perspective. Boston: Houghton Mifflin, 2002.

[9] R. Hanna and S.-Y. Wang, "Dishonesty and Selection into Public Service," Natl. Bur. Econ. Res., 2013.

[10] A. L. Al-Khasawneh, "The Relation between Human Resource Management (HRM) Strategies and Job Loyalty as Practiced at the Public Relations (PR's) Units in the Government Ministries of Jordan," J. Manag. Res., vol. 5, no. 3, p. 146, 2013.

[11] Surjadi, Pengembangan Kinerja Pelayanan Publik. Bandung: Refika Aditama, 2009.

[12] H. L. Packer, The Limits of Criminal Sanction. Stanford University Press. California: Stanford University Press, 1968.

[13] J. H. Skolnick, "Justice Without Trial: Law Enforcement in Democratic Society," in Lawrence M. Friedman dan Stewart Macaulay (ed), Law And The Behavioral Sciences, New York: The Bobbs- Merril Company, 1966, p. 903.

[14] T. Syahuri, "Peran Komisi Yudisial Dalam Mewujudkan Peradilan Bersih dan Berkeadilan," Bandar Lampung, 2011.

[15] A. Hamzah, "Pembangunan Hukum Pidana Indonesia," in Seminar Pengaruh Globalisasi terhadap Hukum Pidana dan Kriminologi Menghadapi Kejahatan Transnasional, 2008. 